[This is the final accepted version of an article published in Internet Histories, volume 2, issue 3-4 (2018).

The version of record may be found at: https://doi.org/10.1080/24701475.2018.1468976 ]

\title{
Technology, ethics and religious language: early Anglophone Christian reactions to 'cyberspace'
}

\section{Peter Webster}

\section{Introduction}

As historians have begun to turn their attention to the recent past, what might be called a 'long 1990s' is starting to appear in some sort of perspective. From the perspective of the liberal capitalist West, the period seemed one of hopefulness, bookended by the eclipse of European communism in 1989-90 and the shock of 9/11 in 2001. One ideological opponent, communism, was thought to be to all intents and purposes neutralised; though it was anticipated by some, the apparently existential threat posed by radical Islamism was not yet part of the cultural imagination (Huntington, 1997, pp.209-18). The West, it seemed, had seen ‘the end of history’ (in Francis Fukuyama’s phrase) and faced a post-millennial future of youthful progress, of 'pure potency [and] limitless possibility' (Mosco, 2004, p.32). Such periodisation needs careful handling. However, this 'long 1990s' provides a useful frame for an imaginative history of the early years of the Web, to set against the technological frame in which much Web history has been written. 
The very recent past has seen a welcome turn towards the historical investigation not only of the early Web, but also of the terms in which both the Web and the Internet were discussed and understood (Natale and Bory, 2017; Barry, 2017). The period between 1992 and 1996 saw a crucial shift in sentiment amongst political and economic elites in the West. The Internet ceased to be imagined as merely a cluster of imperfectly connected technologies that interested computer scientists alone; it became instead an integral system with an agency of its own to promote change: change that could not be resisted, only shaped (Streeter, 2017). In this, as was observed at the time, the Internet was only the latest in a long succession of new technologies to be so understood (Stahl, 1999, p.42). Yet, as Vincent Mosco observed, both Internet and Web were yet to have the kind of transformative effects that are visible at the time of writing. The period of new technologies' full impact is after they become banal, quotidien: after they cease to be 'sublime icons of mythology' (Mosco, 2004, p.6).

Falling into two halves, this article sets out to explore a remarkable effusion of writing in English between 1996 and 2001 that addressed the spiritual and ethical implications of the coming technological revolution. At the same time as the dotcom bubble was inflated, writers across Europe and North America were seeing visions of future utopia and dystopia fashioned by a seemingly unstoppable technology. The article makes an historical argument about the common linguistic archaeology of both secular and religious discussions of the web, and the common shape that those origins give them. The first half pays particular attention to language, and the degree to which discourse about the ethics of the Internet was cast in religious terms. If, as suggested below, the secularisation of language has never been completed (assuming it could ever be), it should be no surprise that moral and ethical debate was often conducted in terms derived from the Christian history of the West. It also suggests that contemporary imaginings about the Web were one example where religious sentiment, broadly defined, had transferred its focus to something other than mainstream religion. (On this phenomenon more broadly, see the analysis of 'technological 
mysticism' in Stahl, 1999, pp.13-34.) The second half pays particular attention to Christian responses and shows that, far from being mere ad hoc reactions to this or that use of the Internet, many of these responses drew on more systematic theologies of culture and technology with roots in earlier periods. It also shows that reactions to 'cyberspace' were closely connected, if indeed not inseparable from, broader concerns about computerisation more generally.

As a contribution to contemporary religious history, this article attempts to map the salient features of a landscape largely devoid of other historiographical signposts, since the writing of the religious history of the 1990s is only just beginning. (For an early and rare assessment of Christian use of the Internet in historical context, see Garnett, 2007). There is now a very considerable literature on ‘online religion' from scholars such as Heidi Campbell, but this has tended both to focus on the present or the very recent past, and on what religious people and organisations have done and said online, rather than with how they have thought and felt about the medium itself (Campbell, 2011; see also the survey at Webster, 2018). While some scholars from the disciplines of theology, religious studies and sociology did engage at the time with the effect of the early Web on the imagination (Brasher, 2001, pp.8-11, 47-56; Beaudoin, 1998, passim; Beckerlegge, 2001, pp.25559), the time is now ripe for an historical investigation of those effects. In order fully to ground the broad conclusions presented here in all their idiographic diversity, a great deal of empirical work of oral history and interrogation of both the archived Web and periodical literature will be required. If this article provides a possible interpretative framework that may aid the work of others, it will have achieved its aim.

\section{Language and the metaphysics of the Internet}

In what is a supposedly hyper-secular age, religious language about technology stubbornly refuses to die. In 2017 the Times Literary Supplement, one of the United Kingdom’s leading general journals of culture and ideas, ran an article under the headline 'Vatican 2.0: how technology 
companies think that they can become God'. Google aims to be "the perfect search engine... like the mind of God” (the phrase of one of the founders Sergey Brin); for Peter Thiel, the American technology entrepreneur and venture capitalist, 'humans are distinguished from other species by our ability to work miracles. We call these miracles technology.' (Earle, 2017). Examples of such use of language are legion, and their prevalence is remarkable in the context of the study of contemporary religious history.

The work of Callum Brown (2009) has redirected historians' attention to language, and specifically to the ways in which British people ceased to tell the stories of their lives in religious terms.

Brown's discursive revolution occurred in the 1960s; scholars since have shown that the previously dominant religious discourse did not so much collapse as adapt. Though many British people no longer would not identify themselves as Christians, their values remained expressed in Christian terms (see, for example, Garnett, Grimley, Harris, Whyte and Williams, 2007, pp.158-63). The common language of the Anglophone world had by the 1990s not succeeded in restructuring itself so as to remove the traces of Christian metaphysics and ethical understandings of the nature of the person, the right form of relationship between people, and the idea of justice and human responsibility. Lost Icons, the 'journal of the 1990s' that Rowan Williams, later archbishop of Canterbury, published in 2000 showed the degree to which Christian (or at the very least, religious) concepts of selfhood persisted in both language and imagination, even if it was their decay that prompted him to write (Williams, 2000).

This section examines the degree to which religious language permeated discussion of the Internet and the Web during the 1990s outside the churches. It asserts, with the Canadian theologian David Lochhead, that the Internet and Web have functioned as a Rorschach inkblot test in which many fears and longings have been glimpsed (Lochhead, 1997, p.10). Faced with a new technology of seemingly limitless yet unpredictable potential, only religious language has been found adequate to address it. A note is necessary here on terminology. In technological terms there are clear 
distinctions between the Internet and the Web, which in turn are related but not coterminous with ‘cyberspace’ and the 'information super-highway', let alone artificial intelligence or 'Virtual Reality’. The thinkers under discussion here rarely make such clear distinctions, using terms imprecisely and promiscuously, and this article does not seek to untangle them. At an historical moment marked by fevered prognostication about things that did not yet exist, the very vagueness of terminology was, as it were, a feature and not a bug. Readers will also note the presence of a wide variety of voices, both religious and not, and from a wide variety of philosophical standpoints. It is not my concern fully to document the varied uses made of these concepts among different kinds of thinkers; the fact that this language had such a wide valency across apparently antithetical fields of discourse is remarkable in itself.

One of the most striking things about contemporary understandings of the Internet is the metaphor of space by means of which it is now almost universally imagined. That it should have become so dominant is in itself a historical curiosity, since in a manner of speaking, the internet exists only as a sequence of transactions: of the sending of data from one computer to another device via a technical infrastructure. The notion that the Internet, or cyberspace, should in some sense constitute a spatial reality, a somewhere in which users may exist, is an historical fact with both very long and very short lines of causation; the former were the subject of the work of the science writer and journalist Margaret Wertheim, born in Australia but at this time based in the USA. The Pearly Gates of Cyberspace (1999) was both a work of long-range cultural history and a commentary on contemporary life. The development of modern cosmology had, Wertheim argued, left the soul homeless. The expansion in the imagination of physical, mappable space to occupy the whole of the conceivable universe had crowded out the idea of any other dimension; there was literally no longer any place for heaven or hell. But humans, she argued, had remained fundamentally dualistic in their understanding of the immortal soul and its existence in some other plane. As a result Wertheim saw in cyberspace a target for the projection of many inchoate longings that had been left without an 
object. Cyberspace provided 'an unexpected escape hatch from the physicalist dogma of the past three centuries.' (Wertheim, 1999, p.38)

There is no claim made here for the influence of Wertheim's thesis, although her publisher, Virago, was not obscure. However, if we are attentive to some of the language used in writing about the Internet in the 1990s, we will see that such a notion, and the related but distinct idea that cyberspace itself was personal - that it possessed, in some way, a soul - was often present, even if beneath the surface. Of course, much of the use of such language is not descriptive, but allusive. Andrew L. Russell (2017) has recently pointed out the parallels between writing about technical pioneers of the Internet and hagiographic writing about Christian saints, but these early figures were not adherents of a new religion as commonly defined; the language is a useful means of framing the past for present purposes. Fred Turner has drawn attention to another imaginative framing of the Internet with particular resonance with an American audience - that of the frontier - which arguably functions in a similar way (Turner, 2006, p.6). Typically promiscuous in its use of language was the 1997 book The Soul of the Internet. Net Gods, Netizens and the Wiring of the World by the Canadian professor of English Neil Randall, published by the Thomson publishing group. Here the 'soul' of the internet is largely synonymous with what we might call culture: the interaction of technical infrastructure and the values of the people who developed and used it. A alternative synonym would be 'spirit', another word with both a precise theological meaning and a wider one denoting the accepted values in line with which actors conduct themselves. (Randall, 1997, pp.347, 351-3) Even here, however, as Evgeny Morozov has shown, certain features of 'the spirit of the Internet' - net neutrality, for instance, or its decentralised nature - have sometimes been taken to be both historically inevitable and eternally fixed, rather than a contingent outcome of history in the way that Manuel Castells outlined (Morozov, 2014, pp.17-35; Castells, 2001, pp.36-63). The 'spirit' or 'soul' of ‘the Internet' has been given a higher ontological status than any mere culture. 
Some thinkers began to make metaphorical play with the Internet, in the sense that the nature of God was a useful metaphor for understanding it. Interviewed (in English) in 1994 for a Canadian journal, the French media theorist Paul Virilio suggested that 'all technologies converge toward the same spot, they all lead to a Deus ex Machina, a machine-God... technologies have negated the transcendental God in order to invent the machine-God.' The development of cyberspace was a 'quest for God. To be God. To be here and there’, an attempt to see panoptically, beyond human perception. 'I am a Christian', Virilio continued, 'and even though I know we are talking about metaphysics and not about religion, I must say that cyberspace is acting like God and deals with the idea of God who is, sees and hears everything.' (Virilio, 1994)

Conversely, the Internet was also itself a useful metaphor by which religious people might think about God. The Swiss theologian and broadcast journalist Michel Kocher addressed the 2001 European Christian Internet Conference, and his address was published online in English. 'Is there perhaps something seriously, essentially religious in the Net?’ he asked: ‘A fundamental anthropological force?' Kocher was at pains to stress that God 'does not have a virtual address.... God is over and beyond, behind an uncrossable barrier, God is apart, God is holy.' But there was metaphorical usefulness for theologians in the nature of the Internet. Just as Christ had issued an invitation to all to come to Him, so was the Internet 'a constant invitation of considerable force'; it had a 'tremendous inviting power ... It is a real presence, in the form of a call.' (Kocher, 2001) God was not to be found on the Internet, but it could be imagined and understood in parallel with Him.

For American readers in particular, there was an intersection between early understandings of the Internet and what David E. Nye called the ‘technological sublime’ (Nye, 2004). New technologies became sublime objects if and when they were able to strike awe, and indeed fear, in those observing them. The Internet seemed to possess at least some of Edmund Burke's characteristics of the sublime object: vastness, infinity and (since few understood how it worked) obscurity. However, at least some of the thinkers examined here went some way beyond the sublime to begin 
to attribute elements of personality to cyberspace itself. This was a rather stronger metaphysic of cyberspace which had grown into the empty imaginative space that Wertheim identified, but with roots in more than one soil (Krüger, 2007). The first medium-term antecedent was Christian, most notably the thought of the Jesuit Teilhard de Chardin, as transmitted by Marshall McLuhan and received by figures such as John Perry Barlow (Turner, 2006, p.165). The second was a form of pantheism associated with the Gaia hypothesis first propounded by the chemist James Lovelock in the 1960s, itself intricately connected with the syncretic chaos of techno-paganism that the American journalist and writer Erik Davis revealed and to which he gave voice in his Techgnosis (1999). The closeness of this complex of ideas to some Buddhist reactions to the early Internet is evident in the work of the American writer and journalist Jeff Zaleski (himself a Buddhist), whose The Soul of Cyberspace was published in 1997 by Harper Collins. Zaleski’s interview with John Perry Barlow reveals how close some came to giving the Internet an independent personality and agency of its own. Does it have a soul, Zaleski asked? Barlow thought so, shown by 'watching it try to get what it appears to want... It’s saying “Create me. Make me. Give me consciousness”... It wants to live and it wants to understand... [it is] a collective organism of mind'. (Zaleski, 1997, pp.47-48)

Christians whose theology was catholic in orientation tended to stress the human making of things as good in itself. God as creator had made the physical world; human work, from the most mundane to the making of high art, was a sharing in that creative activity. The Internet then, as a product of human ingenuity, could be glossed positively in its own right, quite apart from the uses to which it could be put. Not only this, but God had not set up the world as it were like a watch and left it to run on its own devices, but continually intervenes to sustain the whole of the universe. It was a short step from this, via the process theology of Teilhard, to the position taken by the American theologian and technology consultant Jennifer Cobb in her Cybergrace, published in 1998 by the same publisher as Erik Davis. The hand of God could be seen in all of creation as it sustained the 
process of evolution. 'The divine is woven throughout all of reality in the form of creative, responsive love and evolutionary becoming' she argued, and this reality now encompassed both virtual and physical worlds. 'In this sense, the divine permeates the very fabric of the universe..... [w]e are now beginning to see divine creativity emerge not only in the world birthed by nature, but in the world we have made [ie. cyberspace]' (Cobb, 1998, p.12) The suggestion here is not that either Cobb’s or Zaleski’s work was particularly influential or that many readers would necessarily have travelled the whole way with them to the enchanted, conscious Internet. However, Cobb’s work perhaps represents the furthest point to which recognisably Christian theology could extend.

Although this article confines itself to the period before 2001, the scene was by that point set for the idea of a conscious Internet later to fuse with the notion of the singularity. It was a short step from the notion of the 'enchantment' of the network itself to that of a God-like consciousness distributed across many machines linked by that network. The idea of the singularity itself is beyond the scope of this article, but although there was Christian anxiety about Artificial Intelligence in the 1990s and indeed before, it had not yet been connected with the Internet; if there was a threat to human uniqueness from intelligent machines (which is examined further below), those machines were imagined singly (Puddefoot, 1996).

It would seem that most Christians were rather less engaged with the metaphysics of the Internet than thinkers such as Cobb. One such was Brother Richard Oliver, a pioneer of the web for the Roman Catholic Benedictine order of monks, whom Zaleski interviewed by email. Asked about the idea of the evolutionary Web, Oliver replied: 'I have read as much of this kind of rhetoric as I could stand. Where is the evidence for it? ... I see absolutely no evidence of the kind of "convergence” Teilhard imagined.’ How did Brother Richard personally imagine cyberspace, and did God manifest himself there, asked Zaleski. 'Not yet to me, thank God' was the reply; cyberspace was just a 'bunch of electrons temporarily congealed into meaning.' (Zaleski, 1997, pp.118-19) This kind of 
unsentimental, instrumental understanding of the Web was typical of many Christians in the period, but there was also a darker and more dystopian thread of reflection on the idea of a conscious cyberspace. In this, Christian critiques were closely intertwined with a more secular cultural anxiety which dated back some twenty years, and concerned Artifical Intelligence, human autonomy and the fearful power of the machines, to which we shall return.

\section{Christian pragmatism and the ethics of technology}

Some religious critics of communication technologies, and the Internet in particular, were prone to seeing only the message and neglecting the medium. Whilst some Christians questioned particular technologies in principle, rather more were pragmatic in adopting new technologies according to local need, whilst criticising their misuse. (In the case of television, see Bruce, 1990; Grimley, 2014). In the web context, there is now a large literature on the ways in which religious organisations have adopted the Web for their own purposes - disseminating information, providing guidance, reproducing worship and ritual, engaging in debate with others - while also campaigning against pornography, online fraud, hate speech and the spread of disinformation (on this, see the survey at Webster, 2018). But as well as these various critiques of particular things online there was in these early writings the shape of a broader and more abstract analysis of technologies themselves, with significant continuities with earlier Christian ethics.

Who was it within the churches that entered these debates? Thomas Streeter has shown that, in these early years, the technological and intellectual lead was not taken by the most senior figures in organisations, but by younger people in the middle ranks (Streeter, 2011, p.15). This situation is parallelled in Christian debate. Although there were occasional statements from bishops and other senior religious figures, it was not senior clergy that generated the most substantial contributions to these debates. Cybernauts awake!, a report from a working party of the Church of England, was 
relatively unusual in being a quasi-official statement on the matter (Church of England, 1999). (Though the reasons why are beyond the scope of this article, it was also mainly men who entered the published debate on the issues in question; of the eight authors of Cybernauts awake!, only one was a woman.) Some who contributed to the debate were academics working in theological colleges and seminaries: Douglas Groothuis was a teacher of the philosophy of religion and ethics in the evangelical Denver Seminary; David Lochhead a professor of systematic theology in the interdenominational Vancouver School of Theology. In Scotland, Graham Houston was a former university chaplain for the Church of Scotland now working outside formal ministry for the National Bible Society of Scotland; also in the UK, David Pullinger was a teacher, writer and consultant in computing and ethics, a former director of the Society, Religion and Technology project for the Church of Scotland, and a member of the prominent London evangelical church of St Mary, Islington. Patrick Dixon was a British doctor with experience in early IT systems for medical use, who combined this with lecturing and writing on a wide variety of topics concerning technology and Christian ethics.

Neither were these various books published by obscure presses: Baker Books (Groothuis), InterVarsity Press (Houston) and Kingsway (Dixon) were prominent in the evangelical constituency on both sides of the Atlantic; Darton Longman and Todd (Pullinger) was a large general church press in the UK; Lochhead's study was published by the World Council of Churches. Most of these titles were priced and marketed at a general Christian readership beyond the universities. It was also a conversation largely confined within the Anglophone world, and (in fact) largely north America and the UK, with few apparent points of contact with Australia or New Zealand. Most of the sources that these authors cited were read in editions published in either the USA or the UK. When the French scholar Jacques Ellul (discussed below) was referred to, it was in north American editions; almost no literature in languages other than English is cited. It was also the case that the flows of 
influence across the Atlantic were not equally strong. While British authors regularly drew on work published in the USA, American authors referred to British scholars to a much lesser extent.

These thinkers were not writing into an intellectual vacuum, but were in dialogue with Christian reflection on technology in the period immediately before the Web, addressing by various means the question: if technologies were inherently value-laden in their very design, then which Christian principles might be elaborated to decide whether something should or should not be developed? In 1986 a group of scholars from the USA and the Netherlands associated with Calvin College, a school in the USA in the Reformed tradition, had elaborated a systematic theology of technology from first principles (Monsma, 1986). 'Ethics in an age of technology' was the subject of the prestigious Gifford Lectures in natural theology in the University of Aberdeen between 1989 and 1991, given by the American scholar Ian Barbour (1992). As early as 1985, a series of lectures at John Stott's influential evangelical London Institute for Contemporary Christianity had focussed solely on the impact of the computer: David Lyon was a research fellow of Leeds University studying the 'social aspects of information technology' (Lyon, 1986). Earlier again, a particularly critical voice was the Oxford University physicist Michael Shallis in The Silicon Idol (1984). There was here a sense that the churches had in general paid too little attention to technology and that this had to be remedied. The complexity, geographic reach and pervasiveness of a particular group of new technologies - not only the computer, but also television, industrialised agriculture, military weaponry and systems of power generation - meant that a fresh ethical consideration was necessary: 'the works of minds and hands seem to have outstripped those of the heart.' (Monsma, 1986, p.4)

These attempts at a theology of technology in the late 1980s and early 1990s themselves had intellectual antecedents. Some of the writers under review here cited the work of the maverick Roman Catholic priest Ivan Illich; his Tools for Conviviality, first published in the USA in 1973, appeared in mass circulation paperback editions in the UK and elsewhere (Illich, 1975). Easier for 
Christians to assimilate (and particularly influential amongst evangelicals) was the thought of the French theologian Jacques Ellul, whose The Technological Society was published in English in the USA in 1964 and in London soon afterwards.

These Christian thinkers were in some respects in step with a broader cultural scepticism in the 1980s about technology, broadly conceived. By the end of the 1970s, there had been a perceptible swing towards a pessimism about technological change, both a disillusion with what it had purported to offer and alarm about the social and environmental effects (Norman, 1981: 15-26). In 1977 the MIT political scientist Langdon Winner pointed out a marked public concern that technologies had outstripped the political means of controlling either their capabilities or their effects (Winner, 1977). In this particular movement, it is notable that writers with a Jewish heritage were unusually prominent. Though this article is by no means a study of Jewish responses to cyberspace, it should be no surprise that there were significant points of intellectual sympathy between Christian and Jewish thinkers, given the Scriptures shared between the two faiths. Aleks Krotoski recently noted the tendency to make the Internet a scapegoat (a shared concept for Jews and Christians) for other social ills, a point made in 1981 in relation to technology more generally by the writer and engineer Samuel C. Florman (Krotoski, 2014; Florman, 1981). Another Jewish scholar, the sociologist Manfred Stanley, who had fled from Nazi Germany to the USA as a child, wrote in 1978 of the 'technological conscience'. Both these critics and the Christian thinkers with whom they were in dialogue helped to prepare the general tenor of Christian thinking for a much greater scepticism when the pendulum swung again from the pessimism of the 70s back to the euphoric optimism of the early 90s associated with the Internet and Web.

The Christian critique of the mid-1990s clustered around three main themes: the distribution of economic and social power; the impact on human relationships, and the impact of computerisation on understandings of human nature and the relationship between man and God. In each case these 
critiques drew on much older sources of Christian ethical reflection. It was also the case that the critique was often not merely of the Internet, but of computerisation in general, and the way in which the Internet magnified its effects, multiplying some more malign features of the single local machine in a networked context. Of these three themes, the third is treated most extensively here, but all three were the transposition of older concerns into a new context.

To be clear, it is not the argument of this article that all who might have owned the label of Christian reached the same conclusions about the nature and probable impact of cyberspace: the constituency was (and, arguably, always has been) far too diverse for that. Those voices being most heard in this particular discussion were critical, or at the very least cautious. Those who were most comfortable with adopting the Internet for their particular purposes tended not to trouble publishers; there was no parallel genre of published Christian celebration of the Internet to match the critics. In general, it seems to have been Protestant critics, and in particular evangelicals, who were most cautious, in keeping with the typically greater stress among evangelicals on the fallen state of human nature. Despite this diversity, this article nonetheless contends that the particular set of concerns in play - about human relationships, the status of the human person in relation to God, and the right use of human creativity - were common enough that it is meaningful here to treat Christian discourse as a coherent unit of analysis.

\section{Power: political and economic}

Christian concern with economic inequality and the condition of the worker has a long history indeed, from the philanthropic British industrialists of the nineteenth century to the 'Christian sociology' of the inter-war period. Some of these responses to the social damage caused by unrestrained capitalism were reactive, a charitable response to deprivation (Bradley, 2007); others involved a more systematic critique of capitalist assumptions concerning property, the role of finance and the responsibility of the state, such as that of William Temple, archbishop of Canterbury 
(Temple, 1942). Related to this was the growing realisation among Christians in the 1960s and 1970s of the systemic inequality of the world economy and its effects on the economies and societies of the developing world (Brown, 2017, pp.251-260).

It was against this background that Christian critics reacted to the economic effects - observed and predicted - of computerisation and the automation of the workplace. In the mid-1990s few foresaw the full economic effects of the Web, but some critics saw in microcosm some of the issues that later became writ large across the network. Already in the mid-1980s the effects of the computerisation of the office were noted and discussed, with regard to the changing nature of work itself, the new relationship between the worker and their supervisor, now armed with new methods of monitoring and surveillance, and the effects of telecommuting on the working life (Lyon, 1986, pp.38-42). What were the rights of those whose jobs the computerisation of work made redundant, it was asked. Who stood to benefit most from the new forms of employment: were educated men in the West the beneficiaries, at the expense of women in the West and of men and women alike in developing countries? (Barbour, 1992, pp.151-3, 165-6) How should the IT industry be regulated in order that monopoly power over standards, hardware or software was not abused; in Christian terms, how should these forms of knowledge be stewarded if, in the final analysis, all things were a gift of God and belonged to Him ? (Church of England, 1999, pp.33-35) Others asked how it might be ensured that data about persons was treated appropriately. Who (or which organisations) stood to gain economic or political power over others by means of their data? (Lochhead, 1997, pp.87-92)

\section{Relationships and the ethics of behaviour}

The second of the three key planks of the Christian critique of the Web concerned its effect on interpersonal relationships and the ethics of behaviour. The migration of human interaction online posed new variations on older ethical questions, and some new questions entirely. Was it possible to transfer the activity of worship into cyberspace, if worship depended on being bodily present with 
others, and participating communally in shared rituals involving physical things? After some experimentation, many Christians concluded not, but by no means all (Webster, 2018). But there were wider questions about day-to-day online interaction outside specifically religious contexts. If the command of Christ was to love one's neighbour as oneself, who in cyberspace was now the neighbour? (Church of England, 1999, pp.51-54) How was online interaction between individuals already changing the ways in which people related? Would online interaction make it harder or easier to interact as if humans were the children of God, bearers of His image, and thus intrinsically worthy of respect ? Christians were not alone in being acutely concerned about the affordances the Internet gave to hate speech (Lochhead, 1997, pp.83-87). Others were concerned with the subtler effects of anonymity online, as an enabler of deception and a destroyer of trust, both by human actors and by machines presented as humans (Groothuis, 1997, pp.131-36; Pullinger, 2001, p.97; Dixon, 1997, p.146)

\section{Man and machine}

The final cluster of issues that provoked Christian anxiety in the late 1980s and 1990s concerned the relationship between humans and machines. Here were several issues that, in technological terms, were quite distinct: Artificial Intelligence, virtual reality, robotics and the Internet each had their own trajectories of technical development, involving different configurations of ideas, personnel, organisations and capital. However, they became jointly implicated in a broader Christian anxiety about the relationship between man and machine.

One key work in this regard, often cited by the authors under review, was Joseph Weizenbaum's Computer Power and Human Reason (1976, and issued in the UK in 1984 by Pelican Books). An MIT professor, early pioneer of artificial intelligence, and another scholar of Jewish heritage, Weizenbaum's critique centred on a crucial distinction between what computers were capable of being made to do, and what they ought to be used to do. Some activities were the proper province of 
humans alone, even if machines could be made to very closely replicate them, and perform them more quickly and efficiently. Such a critique resonated powerfully with the Christian assertion of the uniqueness of human beings, who were not merely highly developed apes but had a unique status in the created order. Anything that seemed to chip away at the uniqueness of human consciousness was to be resisted. At the same time there was a particular seductiveness about the computer. 'We think and speak of the computer in terms of images which lie close to the core of our own identity as human beings' wrote David Lochhead. 'In all its ambivalence, the computer invites us to invest it with whatever possibilities we choose... We sense in the computer something of ourselves. We react with a mixture of fear and fascination. Thus, the computer becomes for us a demonic beast or a divine deliverer' (Lochhead, 1997, pp.15-16.)

Part of the concern was at the level of metaphor. Just as the Internet had become a metaphor by means of which to think about the nature of God (as discussed above), in previous years the computer had become a means by which to think about human consciousness (Stahl, 1999, p.23). Whether or not the brain was a useful analogy by means of which to understand the computer, there was a danger that the computer would became an analogy for the brain. For Michael Shallis, the computer 'embodies one of man's ideas ... the notion of pure rationality, man's ideal view of his own intelligence.' This was an impoverishment, Shallis argued, since intelligence could never be reduced to pure rationality. But the danger was that the computer, increasingly autonomous and selfpropelling, would lead man 'with his Narcissus-like infatuation with his own created images, to redefine himself in the image of the computer.' (Shallis, 1984, pp.83-84). Concern about the reduction of humans to mere information processors continued to resonate in Christian writing in the 1990s.

The previous section examined Christian concerns about the relational damage of computermediated communication. This, too, was part of a wider anxiety, about the nature of selfhood, in the context of 'postmodernity'. Although it was not always clear what was meant by postmodernity, Christian thinkers in the 1990s were grappling with threats it was thought to pose, particularly in 
relation to the stability of language (Tomlinson, 1995, pp.87-99). The specific concern in relation to technology was with the impact of postmodernity on the self. An extension of the concern about anonymity (examined above) was an anxiety about the de-centred self, a fluidity of identities, made and remade by individuals both online and offline. The term 'cyberspace' was used rather loosely by many, to mean either online spaces or virtual reality as locally hosted, but the concern was the same: the postmodern condition involved 'the death of belief in the unitary self, the hard ego, the irreducible centre of personal identity' (Groothuis, 1997, pp.26-27). In such an 'age of simulation' Christians needed to reassert 'the objective reality of moral order and the primacy of the moral subject within that order' (Houston, 1998, p.184); the Christian notion of the self was stable and unitary, 'rooted in the biblical doctrine of our creation in the image and likeness of God and our possession of an immaterial soul with its own distinctive attributes that persists over time.'

(Groothius, 1997, p.27) Though this critique originated in relation to virtual reality, it coloured Christian thinking about the Internet as a system.

A further thread in the complex knot of Christian anxiety in this period was with the body, and the consequences of a disembodied existence in cyberspace. Not only did some secular futurists suppose that the human personality could be reduced to pure information processing; it also might, at some future time, become reducible to data and executable code that could outlive the physical body to be either incorporated in a new machine body, or absorbed into cyberspace, a secularised nirvana. 'The pioneers of Artificial Intelligence, in quest of the immortal mind... together with their disciples in Artificial Life, cyberspace, and virtual reality’ had, wrote the Canadian historian David Noble, 'trained their minds for transcendence ... taking flight from the world, pointing us away from the earth, the flesh, the familiar' (Noble, 1998, pp.205-7). Some Christians reacted directly to this kind of transhumanist rhetoric. Douglas Groothuis noted the Platonic roots of the transhumanist impulse for 'disincarnation' and the family resemblance it bore both with Buddhism, and with some of the religious expressions of the New Age: ‘creation, incarnation and resurrection are alien 
categories in this scheme'. But Christianity was an embodied religion: the Christian would be resurrected in the body, rather than as an escape from it (Groothuis, 1997, p.37).

Finally, and more broadly, at the moment when the Internet and Web had become the focus of vaulting utopian projections, there was a reaction among some Christians against some of the more overblown rhetoric concerning the creative work of Man. We noted in the introduction some of the allusions to the God-like status of Man as he worked miracles through his new technologies, and more than one writer noted the connection between some themes in technopagan thought and older conceptions of the magical: not for nothing was an early book on Silicon Valley entitled The New Alchemists (Hanson, 1982). 'The computer is sage, seer, shaman’ observed David Lochhead: ‘many people’s first experience of using a computer may seem like a magical moment. A machine responds to our touch. For some the magic is like a spell which binds them to the computer as an object of fascination; for others it is unwelcome' (Lochhead, p.16). But such ideas caused some unease, and provoked attempts, explicit or implicit, to reassert the ultimate dependence of human creativity on God as creator, despite the apparently magical feats that could now be performed.

Such vaulting human ambition had an historical context, explored in David Noble's 1997 study The Religion of Technology. The Divinity of Man and the Spirit of Invention. Another writer with a Jewish heritage, Noble's historical survey ended with a scintillating attack on the excesses of the contemporary religion of technology. The long-range history of technology had been, he argued, one of a human striving for self-perfection and mastery of the natural world, a profoundly religious impulse that had become a danger once the Christian framework of control in which it developed fell away in the twentieth century. Freed from any consciousness of human fallibility, the prophets of the technological millennium sought to 'mak[e] the world over to conform to their vision of perfection’ while amongst the public, ‘the religion of technology has become the common enchantment. The expectation of ultimate salvation through technology... has become the unspoken 
orthodoxy, [reinforced by] a millennarian yearning for new beginnings.' (Noble, 1997, p.207) The foundations for what Evgeny Morozov later called 'solutionism' had been in place for a long time (Morozov, 2014, pp.1-16). Christian thinkers in the late 1980s and 1990s reasserted that, try as he might, mortal Man would never be able wholly to overcome the imperfections of his fallen and flesh-bound state by means of technology. David Lyon, looking ahead from 1986, saw the danger of ‘silicon idolatry', but there was an opportunity to choose not to 'attempt “to be as God” by creating new beings “in our own image.”' The Tower of Babel was the salient image: 'proud self-sufficiency and delusions of deity were its building bricks. Confusion of communication was its divine punishment.' (Lyon, 1986, pp.85, 72)

\section{Conclusion}

In 1984, Hans Jonas, the German-born American philosopher (and yet another of the several Jewish thinkers encountered in this story), argued that the 'lengthened reach’ and unpredictable consequences of technology dictated a new 'imaginative "heuristics of fear”, a pragmatic decision to 'give the prophecy of doom priority over the prophecy of bliss' (Jonas, 1984, p.ix). By and large, the majority of Christians who engaged with the ethics of the computer followed his lead. In his Silicon Idol, Michael Shallis reached the conclusion that the computer was so fundamentally problematic a technology that only a total rejection of it would do (Shallis, 1984, pp.176-177), though few other Christian critics followed Jonas' logic to this extreme. Some responded simply to the likely effects of particular manifestations of life online, seeing ethical challenges in relation to economic and social exclusion, and the subtler impact on the health of interpersonal relations; others, though in the minority, elaborated a semi-mystical evolutionary understanding of the Web that had parallels with those more influenced by pagan or Buddhist thought. Others again set aside high-flown imaginings, either positive or negative, and adopted the Web as a pragmatic means of achieving their ends. This article has, however, concentrated in particular on some of the reactions to shifts in the conceptual vocabulary of the West in relation to personality and the soul, man's 
capabilities and limitations, and the relationship between man and God. It was no surprise that some Christian thinkers saw a particular threat to core doctrines in the overheated discourse of the 1990s.

This thinking, however, did not occur in isolation from the sweep of Anglophone social thought or longer-term Christian ethical reflection. The Christian critique of technology in the 1980s and 1990s was closely related to a more general reaction in the 1970s and 1980s to the utopian rhetoric of the post-war decades. I have also tried to suggest that the language in which the Internet and Web have been discussed in general has been infused at every level with religious imagery, whether it be the soul of the Internet or the miracles of technology. There was little in this complex bricolage of concepts and images from several religious traditions to form anything like a coherent theology of the Internet, and the very imprecision of the concepts involved added to their valency across apparently antithetical fields of discourse. Indeed, this very syncretism was a source of discomfort to those Christians attempting to understand it, and was instrumental in provoking the reactions examined here. But the case of cyberspace suggests that the linguistic secularisation of the Anglophone West was, in the 'long 1990s' at least, incomplete.

\section{Acknowledgments}

The author gratefully acknowledges the help of Stephen Parker, Ralph Schroeder and Alwyn Turner (who read the draft manuscript), the editors, and the two anonymous peer reviewers.

\section{Bibliography}

Barbour, I. (1992). Ethics in an age of technology.The Gifford Lectures 1989-1991.Volume 2. London: SCM Press.

Barry, M. (2017). Untangling the threads: public discourse on the early Web. In N. Brügger (ed.), Web 25. Histories from the first 25 years of the World Wide Web (pp.57-76). New York: Peter Lang. Beaudoin, T. (1998). Virtual faith. The irreverent spiritual quest of Generation X. San Francisco: Jossey-Bass. 
Beckerlegge, G. (2001). Computer-mediated religion: religion on the Internet at the turn of the twenty-first century. In: G. Berckerlegge (ed). From sacred text to internet. Aldershot: Ashgate.

Bradley, I. (2007). Enlightened entrepreneurs. Business ethics in Victorian Britain. Oxford: Lion, $2^{\text {nd }}$ edition.

Brasher, E. B. (2001). Give me that online religion. San Francisco: Jossey-Bass.

Brown, C. G. (2009). The Death of Christian Britain: Understanding secularisation 1800-2000 (2nd ed.). Abingdon: Routledge.

Brown, M. (2017). Global poverty and justice. In: J. Morris (ed.) The Oxford History of

Anglicanism: volume IV: Global western Anglicanism, c.1910-present. Oxford: Oxford University Press (pp.243-267)

Bruce, S. (1990). Pray TV: Televangelism in America. London: Routledge.

Campbell, H. (2011). Internet and religion. In: M. Consalvo and C. Ess (eds) The Handbook of Internet Studies. Chichester: Wiley-Blackwell (pp.232-50)

Castells, M. (2001). The Internet galaxy. Reflections on the Internet, business and society. Oxford: Oxford University Press.

Church of England (1999). Cybernauts awake! Ethical and spiritual implications of computers, information technology and the Internet. London: Church House Publishing.

Cobb, J. (1998). Cybergrace. The search for God in the digital world. New York: Crown.

Davis, E. (1999). Techgnosis. Myth, magic and mysticism in the age of information. London: Serpent's Tail.

Dixon, P. (1997). Cyberchurch. Christianity and the Internet. Eastbourne: Kingsway.

Earle, S. (2017). Vatican 2.0. How technology companies think they can become God. Times Literary Supplement, 17 November, 3-4.

Ellul, J. (1964). The technological society. New York: Knopf.

Florman, S.C. (1981). Blaming technology: the irrational search for scapegoats. New York: St Martin's Press.

Garnett, J. (2007). Internet generation: computer-mediated communication and Christianity. In Garnett, J., Grimley, M., Harris, A., Whyte, W. \& Williams, S. (Eds) (2007). Redefining Christian Britain; post 1945 perspectives (pp.148-57). London: SCM.

Garnett, J., Grimley, M., Harris, A., Whyte, W. \& Williams, S. (Eds) (2007). Redefining Christian Britain; post 1945 perspectives. London: SCM.

Grimley, M. (2014). Anglican Evangelicals and anti-permissiveness: the Nationwide Festival of Light, 1971-1983. In A. Atherstone and J. Maiden (Eds) Evangelicalism and the Church of England in the Twentieth Century (pp.183-205). Woodbridge: Boydell. 
Groothuis, D. (1997). The soul in cyberspace. Grand Rapids: Baker.

Hanson, D. (1982). The New Alchemists. Silicon Valley and the microelectronics revolution (Boston, MA: Little, Brown)

Houston, G. (1998). Virtual morality. Christian ethics in the computer age. Leicester: Apollos (Inter-Varsity Press)

Huntington, S. P. (1997). The clash of civlizations and the remaking of world order. London: Simon and Schuster.

Illich, I. (1975). Tools for conviviality. London: Fontana.

Krotoski, A. (2014). Inventing the Internet: scapegoat, sin eater and trickster. In M. Graham and W.H. Dutton (Eds), Society and the Internet. How networks of information and communication are changing our lives (pp.23-35). Oxford: Oxford University Press.

Jonas, H. (1984). The imperative of responsibility. In search of an ethics for the technological age. Chicago and London: University of Chicago Press.

Kocher, M. (2001). Virtual links, real presence: the Internet and the churches. Paper given at the sixth European Christian Internet Conference, Copenhagen. Accessed at:

https://web.archive.org/web/20041217204906/http://www.ecic.info:80/archive/ecic6/papers01/koch er.html

Krüger, O. (2007) Gaia, God, and the Internet: The History of Evolution and the Utopia of Community in Media Society. Numen 54:2, 138-173

Lochhead, D. (1997). Shifting realities: information technology and the Church. Geneva: World Council of Churches.

Lyon, D. (1986). The silicon society. How will information technology change our lives? Tring: Lion.

Monsma, S., ed. (1986). Responsible technology: a Christian perspective. Grand Rapids: Eerdmans. Morozov, E. (2014). To save everything, click here. Technology, solutionism and the urge to fix problems that don't exist. London: Penguin.

Mosco, V. (2004). The Digital Sublime. Myth, power and cyberspace. Cambridge, MA: MIT Press. Natale, S. and P. Bory (2017). Constructing the biographies of the Web: an examination of the narratives and myths around the Web's history. In Brügger, Web 25. Histories from the first 25 years of the World Wide Web (pp.29-42). New York: Peter Lang.

Noble, D. (1997) The Religion of Technology. The Divinity of Man and the Spirit of Invention. New York: Knopf.

Norman, C. (1981). The god that limps: science and technology in the Eighties. New York: Norton. Puddefoot, J. (1996) God and the mind machine. Computers, Artificial Intelligence and the human soul. London: SPCK. 
Pullinger, D. (2001). Information technology and cyberspace. Extra-connected living. London:

Darton, Longman and Todd.

Nye, D. E. (1994). American technological sublime. Cambridge, MA: MIT Press.

Randall, N. (1997). The soul of the Internet. Net gods, netizens and the wiring of the world. London: International Thomson Computer Press.

Russell, A. L. (2017). Hagiography, revisionism \& blasphemy in Internet histories. Internet Histories 1:1, 15-25.

Shallis, M. (1984). The Silicon Idol. The micro revolution and its social implications. Oxford:

Oxford University Press.

Stahl, W. A. (1999). God and the chip. Religion and the culture of technology. Waterloo (Ontario):

Wilfred Laurier University Press.

Stanley, M. (1978). The technological conscience. Survival and dignity in an age of expertise. New York: Free Press.

Streeter, T. (2011). The net effect. Romanticism, capitalism and the Internet. New York: New York University Press.

Streeter, T. (2017). The Internet as a structure of feeling: 1992-1996. Internet Histories, 1(1), 79-89. Temple, W. (1942). Christianity and Social Order. London: Penguin.

Tomlinson, D. (1995). The post-evangelical. London: SPCK.

Turner, F. (2006). From counterculture to cyberculture: Stewart Brand, the Whole Earth Network, and the rise of digital utopianism. Chicago: University of Chicago Press.

Virilio, P. (1994). Cyberwar, God and television: interview with Paul Virilio. CTHEORY, 1

December, accessed http://www.ctheory.net/articles.aspx?id=62 (accessed 23 November 2017).

Webster, P. (2018). Religion in Web history. In N. Brügger and I. Milligan (Eds.) The Sage

Handbook of Web History. London: Sage (in press).

Weizenbaum, J. (1976). Computer power and human reason. From judgment to calculation. San Francisco: W.H. Freeman.

Wertheim, M. (1999). The pearly gates of cyberspace: a history of space from Dante to the Internet. London: Virago.

Williams, R. (2000). Lost icons: reflections on cultural bereavement. London: T. \& T. Clark.

Winner, L. (1977). Autonomous technology. Technics-out-of-control as a theme in political thought. Cambridge, MA: MIT Press.

Zaleski, J. (1997). The soul of cyberspace. New York: Harper Collins. 